\title{
Performance Evaluation of Happy Seeder for Wheat Sowing in Combine Harvested Paddy Field
}

\author{
Navneet Kumar Dhruwe* and V. M. Victor \\ FMPE, SVCAET\& RS, IGKV, Raipur, C.G., India \\ *Corresponding author
}

\section{A B S T R A C T}

Keywords

Happy seeder, Zero till drill, Paddy and Residue

Article Info

Accepted:

15 December 2020

Available Online:

10January 2021
The performance evaluation of happy seeder was carried out in combine harvested paddy field at Agriculture farm, IGKV, Raipur (C. G.). The performance and evaluation of the happy seeder with zero till drill and show its effectiveness over the sowing technique, it was done on the basis of field capacity, field efficiency, actual field capacity, fuel consumption and cost of operation, the compression of economics of operation of happy seeder with conventional method of sowing wheat in combined harvested paddy field, to prove the effectiveness. The operating speed was varying from 2.5 to $3.5 \mathrm{~km} / \mathrm{h}$ to evaluate the variables. The field efficiency of happy seeder was $74.72 \%$ and $63.33 \%$ for zero till drill at operating speed of $3.5 \mathrm{~km} / \mathrm{h}$. The crop residue is heavy which was collected by sampling. The cost of operating per hectare by happy seeder was Rs.2382.70/and cost of operation per hectare by zero till-drill (+ straw collected by manually) was Rs. 3200/. Therefore cost of operational with happy economical as compared to zero till drill by Rs. $817.30 /$ per hectare. But happy seeder is unique technique for sowing wheat in combine harvested paddy field.

\section{Introduction}

Rice is the major crop of Chhattisgarh. The increasing constraints of labour and time have led to the adoption of mechanized farming in highly intensive rice system. In Chhattisgarh, mostly the paddy and wheat crops are harvested by combines. The total crop residue generated in India and Chhattisgarh State was 501.73 and 11.25 million tonne respectively (MNRE, 2009). Burning is the normal and easiest method of crop residue management option as it interferes with tillage and seeding operations for the next crop.
Residue burned by the farmers in India and Chhattisgarh State were 92.81 and 0.83 million tonne, respectively (Pathak et al., 2010). Presently, more than 80 per cent of total rice straw produced annually is being burnt by the famers in 3-4 weeks during OctoberNovember (Singh et al., 2010). The gaseous emissions from burning of rice straw analyzed 70 per cent $\mathrm{CO}_{2}, 7$ per cent $\mathrm{CO}, 0.66$ per cent $\mathrm{CH}_{4}$ and 2.09 per cent $\mathrm{N}_{2} \mathrm{O}$. Substantial loss of plant nutrients (especially $\mathrm{N}$ and $\mathrm{S}$ ) and organic carbon occurs during burning of crop residues, which has important implications for soil health (Singh et al., 2005). 
Agricultural fires are on the increase in India because of changes in mechanized harvesting, cropping patterns and water stress (Zhang, et al., 2019). While recent interest has focused on the impacts on air pollution (Liu et al., 2019; Cusworth et al., 2018), evidence also points to their contribution to short lived climate pollutants, such as methane and black carbon, across central and southern India (Sarkar et al., 2018). The reduction of shortlived climate pollutants, the second largest contributor to climate change (Bond et al., 2013), offer an opportunity to mitigate climate change over a shorter time period

Different techniques for crop residue management i.e., mulching, soil incorporation etc. Straw, cloves, leaves, corn cob, and sawdust like crop residue and other plant waste are widely and considerably used as mulch because they are cheap and often readily available. It permits water to enter in the soil easily, when maintain an adequate level. The Mulching with these materials help reducing the loss due to evaporation and increased the water content in the soil. Mulching is a very good and effective way to improve the retention of water and to increase the nutrient content of the soil. The use of crop residue and other plant waste as mulch can improves the microbial activity in the soil and increases the number of worms. It further results into the reduction of weed growth in the field. Reduction in evaporation, moisture retention, and prevention of soil erosion, control over weeds and addition of nutrients to the soil are some of the benefit of the mulching. Similarly, it has some demerits as due to the heavy mulching over a period of many years can result into the build-up of soil over the crown area of the plants.

Different straw management machinery available, like that happy seeder, Rotavator, Mulcher, disc harrow and zero till seed drill. The Happy Seeder is a tractor mounted implement that combines a ZT seeder with a straw management unit. The latter comprises of serrated rotating flails attached to a roller that shreds and clean the residues in front of the tyne openers and then deposits the residue around the seeded row as mulch. This is done in one simple operation of direct-drilling in the presence of standing as well as loose surface residues. The residue left on the surface as mulch helps reduce evaporation losses, suppresses weed growth, buffers soil moisture and temperature, and facilitates a more efficient uptake of water and nutrients by plant roots (Sidhu et al., 2015; Singh et al., 2015). The use of the HS also reduces labour requirements for crop establishment by as much as $80 \%$, irrigation needs by $20-25 \%$, and herbicide use by as much as $50 \%$ (Saunders et al., 2012). It further reduces fuel use and improves productivity, particularly under climatic stress conditions (Aryal et al., 2016; Saunders et al., 2012; Sidhu et al., 2015). The HS works best in combination with a simple straw spreading mechanism, called the "Super Straw Management System'(Super SMS) that can be attached to the combine harvester, which enables uniform spreading residue across the harvesting width. The development of the Super SMS enhances the efficiency of the HS and improves crop establishment and yields (Lohan et al., 2018; NAAS, 2017). Approximately 11,000 HS are already in use in north-west India, of which over $80 \%$ operate in Punjab (personal communication with machine manufacturers). Eighteen manufacturers currently produce the HS.

\section{Materials and Methods}

The happy seeder and zero till drill were evaluated wheat in the combine harvested paddy field where wheat was sown at agriculture field, IGKV, Raipur (C. G.). These experiments were conducted in the year 20182019 after the combine harvesting of paddy 
crop (Fig. No.1 and Fig.No. 2). The test field selected for the testing of the machine was nearly levelled. The auxiliary fuel tank and stopwatch were all initialized for the test run and initial observations were recorded. The machine was run at the required speed in the chosen gear. Initial five meter of test run was used as idle run to obtain a steady state speed conditions. After the idle run, test run was followed. In the beginning of the test run, fuel flow meter was switched on. At the end of the test run, observations were recorded for the time taken to cover the test run and. fuel consumed respectively. The soil of the experimental field was vertisol. The soil was not being saline $\mathrm{pH}$ ranging from 7.2 to 7.8 . The average bulk density is $1.6 \mathrm{~kg} / \mathrm{cc}$, and the average moisture content was found $16.37 \%$ (db).The detailed specification of the used happy seeder was provided in the table No.1.

\section{Results and Discussion}

The following variables are evaluated for happy seeder and zero till drill actual field capacity, field efficiency, fuel consumption and cost of operation. Forward speed taken as independent variable cost for the operation the following data as shown in Table 2 and 3. The field capacity of happy seeder at $3.5 \mathrm{~km} / \mathrm{h}$ was $0.59 \mathrm{ha} / \mathrm{hr}$ and for zero till drill 0.378 ha/hr. The field efficiency for happy seeder $74.72 \%$ and for zero till drill was $63.33 \%$. The fuel consumption with happy seeder for sowing wheat varied from 13.34 to $13.73 \mathrm{l} / \mathrm{ha}$ and for zero till drill 6.33 to $8.86 \mathrm{l} / \mathrm{ha}$ at different operating speed. The cost of operating per hectare by happy seeder was Rs. 2382.70/ and cost of operation per hectare by zero till drill + tillage operations was Rs. 3200/.

Table.1 Specifications of happy seeder

\begin{tabular}{|c|c|c|}
\hline Sr. No. & Particulars & Specification \\
\hline 1. & Horse Power Requirement, hp & $45-55 \mathrm{hp}$ tractor with double clutch \\
\hline 2. & Capacity, ha/h & $0.25-0.35$ \\
\hline 3. & Weight of machine, $\mathrm{kg}$ & 550 \\
\hline 4. & Working width of machine, $\mathrm{mm}$ & 2200 \\
\hline 5. & Row to row distance, $\mathrm{mm}$ & 225 \\
\hline 6. & No. of rows & $9-12$ \\
\hline 7. & Type of Furrow openers & Inverted "T" type \\
\hline 8. & Rotor drum diameter, $\mathrm{mm}$ & 750 \\
\hline 9. & Rotor diameter, $\mathrm{mm}$ & 140 \\
\hline 10. & Ground clearance of furrow opener, $\mathrm{m}$ & 0.30 with working PTO \\
\hline 11. & Rotor speed, rpm & 1360 at $540 \mathrm{rpm}$ of tractor PTO \\
\hline 12. & Types of flail blades & Reversible straight gamma type \\
\hline 13. & Flails length from rotor surface, $\mathrm{mm}$ & 240 \\
\hline 14. & Blade length, mm & 165 \\
\hline 15. & Bottom width of blade, $\mathrm{mm}$ & 85 \\
\hline 16. & Top width of blade, $\mathrm{mm}$ & 50 \\
\hline 17. & Blade Overlap with furrow openers, mm & 60 \\
\hline 18. & $\begin{array}{l}\text { Horizontal clearance between the edges of the } \\
\text { blades, } \mathrm{mm}\end{array}$ & 75 \\
\hline 19. & No. of Depth wheels & Two nos. with adjustable depths \\
\hline 20. & Minimum Diameter of Ground Wheel, mm & 550 \\
\hline 21. & No. of lugs on periphery of GW & 15 (with sharp and long edges) \\
\hline
\end{tabular}


Table.2 Performance of Happy seeder used for paddy residue management

\begin{tabular}{|c|c|c|c|c|}
\hline $\begin{array}{c}\text { Speed } \\
\mathbf{( k m / h )}\end{array}$ & $\begin{array}{c}\text { TFC } \\
\text { (ha/h) }\end{array}$ & $\begin{array}{c}\text { EFC } \\
\text { (ha/h) }\end{array}$ & $\begin{array}{c}\text { Field } \\
\text { Efficiency (\%) }\end{array}$ & $\begin{array}{c}\text { Fuel } \\
\text { Consumption (1/ha) }\end{array}$ \\
\hline $\mathbf{2 . 5}$ & 0.55 & 0.4 & 72.73 & 13.34 \\
\hline $\mathbf{3 . 0}$ & 0.66 & 0.5 & 75.25 & 13.65 \\
\hline $\mathbf{3 . 5}$ & 0.77 & 0.59 & 76.19 & 13.73 \\
\hline
\end{tabular}

Table.3 Performance of zero till drill used after paddy residue management

\begin{tabular}{|c|c|c|c|c|}
\hline $\begin{array}{c}\text { Speed } \\
\mathbf{( k m / h )}\end{array}$ & $\begin{array}{c}\text { TFC } \\
\text { (ha/h) }\end{array}$ & $\begin{array}{c}\text { EFC } \\
\mathbf{( h a / h )}\end{array}$ & $\begin{array}{c}\text { Field } \\
\text { Efficiency } \mathbf{( \% )}\end{array}$ & $\begin{array}{c}\text { Fuel } \\
\text { Consumption (1/ha) }\end{array}$ \\
\hline $\mathbf{2 . 5}$ & 0.44 & 0.31 & 67 & 6.33 \\
\hline $\mathbf{3 . 0}$ & 0.54 & 0.35 & 65 & 8.79 \\
\hline $\mathbf{3 . 5}$ & 0.64 & 0.37 & 58 & 8.86 \\
\hline
\end{tabular}

Fig.1 Happy seeder

Fig.2 Zero till drill

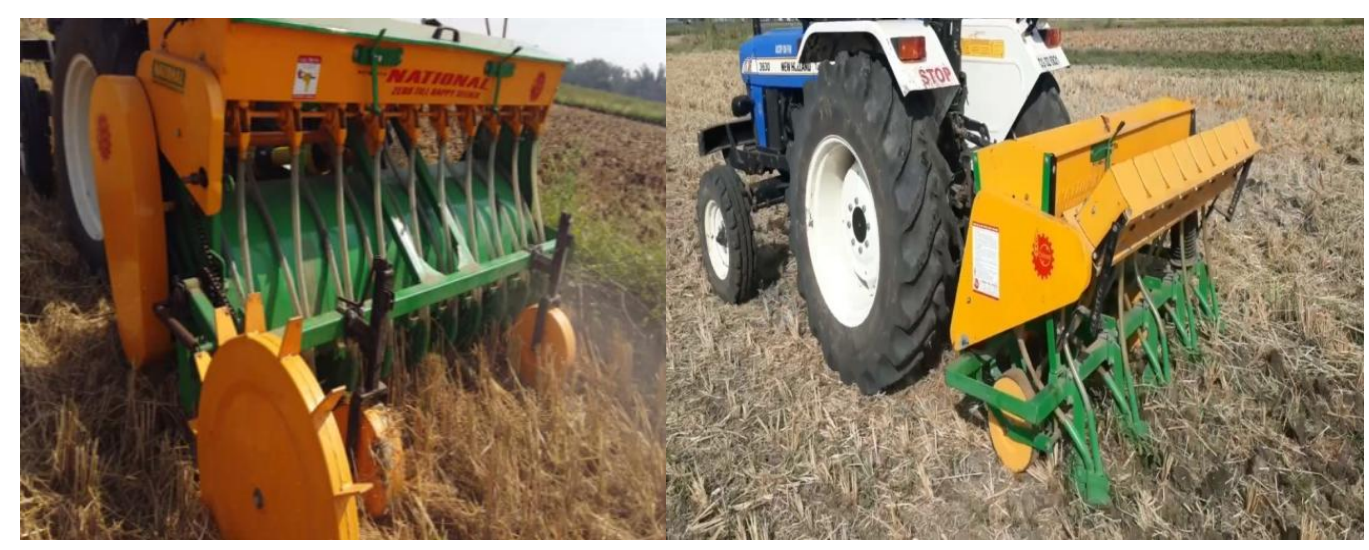

\section{Evaluation of happy seeder}

Wheat was sown with the happy seeder into standing rice residue or bare soil on three days in October 2018 with vertisol soil. The previous rice crop had been harvested with a combine harvester with a cutting height 30 to $35 \mathrm{~cm}$. Average rice dry straw load in each experiment were varied from 4 to 7 tonne/ha dry height at the time of rice harvest. In other field the wheat was sown by the zero till drill.

In conclusion the happy seeder of ten furrow opener was tested for its performance in the month of October 2018 at Agriculture field in
Raipur. The performance of the happy seeder with respect to actual field capacity, field efficiency fuel consumption cost of operation and crop residue condition were studied and compared to conventional method on the basis of result obtained as discussed in result, in the following conclusions were drawn.

The operating speed of happy seeder could be varied from 2.5 to $3.5 \mathrm{~km} / \mathrm{h}$, working of happy seeder was found to be optimum at the speed of $3.5 \mathrm{~km} / \mathrm{h}$.

The fuel consumption with happy seeder for sowing wheat varied from 13.34 to 13.73 1/ha 
and for zero till drill 6.33 to 8.86 1/ha at different operating speed.

The field capacity of happy seeder at $3.5 \mathrm{~km} / \mathrm{h}$ was $0.59 \mathrm{ha} / \mathrm{hr}$ and for zero till drill 0.378 $\mathrm{ha} / \mathrm{hr}$

The field efficiency for happy seeder $74.72 \%$ and for zero till drill was $63.33 \%$

The cost of operation per hectare by happy seeder was Rs. 2098.65 and cost of operation per hectare by zero till drill (+ straw collected by manually) was Rs. 3106.38. Therefore cost of operational with happy seeder is economical as compared to zero till drill by Rs. 1008.38per hectare.

The crop residue was $0.48 \mathrm{~kg} / \mathrm{m}^{2}, 0.488 \mathrm{~kg} / \mathrm{m}^{2}$ and $0.620 . \mathrm{kg} / \mathrm{m}^{2}$ of different plots for happy seeder. The crop residue was found heavy.

\section{References}

Aryal, J. P., Sapkota, T. B., Stirling, C. M., Jat, M. L., Jat, H. S., Rai, M., Mittal, S., \&Sutaliya, J. M. (2016). Conservation agriculturebased wheat production better copes with extreme climateevents than conventional tillage-based systems: A case of untimely excess rainfall in Haryana, India. Agriculture, Ecosystems and Environment, 233, 325-335.

Bond, T. C., Dhoerty, S.J., Fahey, D. W., Forster, P.M. 2013. Bounding the role of black carbon in the climate system: A scientific assessment. J.Geophys.Res. Atmos. 118 (11) 5380-5552

Cusworth, D. H.,Mickley, J. L., Sulprizio, P. M., Liu, T., Marlier, E. M., FriesS, R. D., Guttikunda, S. K. and Pawan Gupta. 2018. Quantifying the influence of agricultural fires in northwest India on urban air pollution in Delhi, India. Environ. Res. Lett. (13), 1-11

Lohan, S. K., Jat, H. S., Yadav, A. K., Sidhu, H. S., Jat, M. L., Choudhary, M., Peter,
J. K., \& Sharma, P. C. (2018). Burning issues of paddy residue management in north-west states of India. Renewable and Sustainable Energy Reviews, 81, 693-706.

Ministry of new and renewable energy Resources

(2009).www.mnre.gov.in/relateblinks/.

NAAS.(2017). Innovative viable solution to rice residue burning in rice-wheat cropping system through concurrent use of super straw management system-fitted combines and turbo Happy Seeder.Policy Brief No. 2.National Academy of Agricultural Sciences.

Pathak H, Bhatia A, Jain N and Aggarwal PK (2010) Greenhouse gas emission and mitigation in Indian agriculture - A review, In ING Bulletins on Regional Assessment of Reactive Nitrogen, Bulletin No. 19 (Ed. Bijay-Singh), SCON-ING, New Delhi, 34 p

R., Gravuer, K., Bossange, A. V., Mitchell, J., \& Scow, K. (2018).Long-term use of cover crops and no-till shift soil microbial community life strategies in agricultural soil. PLOS ONE, 13(2), e0192953.

Sarkar, S. Singh, R. P. and Chauhan, A. 2018. Crop Residue management in northern India: increasing threat to grater India. J.Geophys.Res.Atmos. 6920- 69340

Saunders, C., Davis, L., \& Pearce, D. (2012).Rice-wheat cropping systems in India and Australia, and development of the Happy Seeder. ACIAR Impact Assessment Series Report No. 77. Australian Centre for International Agricultural Research. Schmidt,

Sidhu, H. S., Singh, M., Singh, Y., Blackwell, J., Lohan, S. K., Humphreys, E., Jat, M. L., Singh, V., \& Singh, S. (2015).Development and evaluation of the Turbo Happy Seeder for sowing wheat into heavy rice residues in NW India. Field Crops Research, 184, 201- 
212.

Singh, M. and Shukla, L. N. 2005. Sowing performance of experimental no-till drill with straw thrower attachment in combine harvested paddy field. $J$ Res Punjab Agric Univ. 42(4):463-73.

Singh, Y., Singh, M., Sidhu, H. S., Humphreys, E., Thind, H. S., Jat, M. L., Blackwell, J., \& Singh, V. (2015). Nitrogen managementfor zero till wheat with surface retention of rice residues innorth-west India. Field Crops Research, 184, 183-191.
Singh, Y., Thind, H. S. and Sidhu, H. S. 2010.Management Options for Rice Residues for Sustainable Productivity of Rice-Wheat Cropping System.J Res Punjab agric Univ. 51 (3 \& 4) : 209-220. Zhang, L., Liu, W., Hou, K., Lin, J., Song, C., Zhou, C., Huang, B., Tong, X., Wang, J., Rhine, W., Jiao, Y., Wang, Z., Ni, R., Liu, M., Zhang, L., Wang, Z., Wang, Y., Li, X., Liu, S.\&Wang, Y.2019. Air pollution exposure associates with increased risk of neonatal jaundice. Nature Communications.1-9.

\section{How to cite this article:}

Navneet Kumar Dhruwe and Victor, V. M. 2021. Performance Evaluation of Happy Seeder for Wheat Sowing in Combine Harvested Paddy Field. Int.J.Curr.Microbiol.App.Sci. 10(01): 25422547. doi: https://doi.org/10.20546/ijcmas.2021.1001.294 